\title{
ON SOME NEW INTEGRO-DIFFERENTIAL INEQUALITIES RELATED TO WEYL'S AND HEISENBERG'S TYPE INEQUALITY
}

\author{
QING-HUA MA AND JOSIP PEČARIĆ
}

Abstract. In the present paper some new integro-differential inequalities are obtained, which generalize some results of Pachpatte and Pečarić at ec and derive some new generalizations of Weyl and Heisenberg type inequalities.

Mathematics subject classification (2000): 26D15, 26D20.

Key words and phrases: Integral inequalities, Weyl-type, Heisenberg-type, weight function, Holder inequality, Minkowski inequality.

\section{REFERENCES}

[1] M. Alić, C. E. M. PEARCE AND J. PEČARIĆ, On some discrete Weyl-type inequalities of Pachpatte, Indian J. Pure Appl. Math., 27 (6) (1996), 575-579.

[2] M. Alić, Z. HANJŠ AND J. PEČARIĆ, Eurther generalisation of some discrete Weyl-type inequalities, Rad HAZU, to appear.

[3] D. C. BENSON, Inequalities involving integrals of functions and their derives, J. Math. Anal. Appl., 17 (1967), 292-308.

[4] F.BERNIS, Compactness of the support for some nonlinear elliptic problems of arbitrary order in dimension N, Comm. Partial Differential Equations, 9 (1984), 271-312.

[5] B.FIORKLEWICZ, On the integral inequalities of Weyl type, Colloq. Math., 49 (1984).

[6] G. H. Hardy, J. E. LitTlewood and G. Pólya, Inequalities, Cambridge Univ. Press, Cambridge, 1934.

[7] H. P. HEINING AND M. K. SMITH, Estensions of Heisenberg-Weyl inequality, Internat. J. Math. and Math. Sci., 9 (1986), 185-192.

[8] D. S. Mitrinović, J. K. PEČArić AND A. M. FInK, Inequalities Involving Functions and Their Integrals and Derivatives, Dortlrecht/Boston/London, Kluwer Academic Publishers.

[9] B. G. Pachpatte, On some inequalities of the Weyl type, An. St. Univ. Al. I. Cuza, Iasi, I a Mat., Tom. XL (1994), 89-95.

[10] J. PEČARIĆ AND Z. HANJŠ, More general inequalities of Weyl type, Anal. Sti. Univ. "Al. I. Cuza", XLVI, S. Ia, Mathematica (2000), 307-317.

[11] H. WEYL, The Theory of Groups and Quantum Mechanics (English translation), Dover, New York, 1931. 